\title{
Tocotrienol-rich Fraction
}

National Cancer Institute

\section{Source}

National Cancer Institute. Tocotrienol-rich Fraction. NCI Thesaurus. Code C101518.

An orally available nutritional supplement containing high amounts of the vitamin E family member tocotrienol with antioxidant, hypolipidemic and potential immunomodulating and antiproliferative activity. Upon oral administration, tocotrienol-rich fraction (TRF) accumulates in tumor cells and induces cell cycle arrest, programmed cell death, and inhibits tumor cell proliferation. In addition, this agent suppresses 3-hydroxy-3methylg lutaryl coenzyme A (HMG CoA) reductase activity and inhibits angiogenesis. Rice bran oil, palm oil and annatto seed oil are common sources of TRF. 